Neurolmages

Enhanced T1

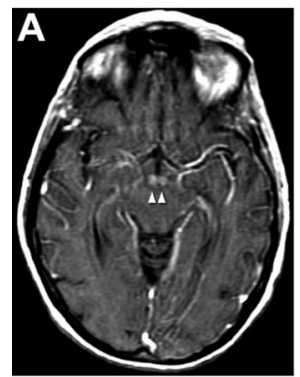

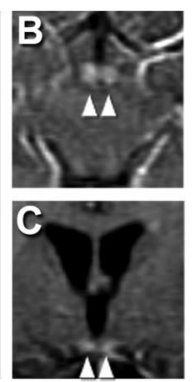

FLAIR

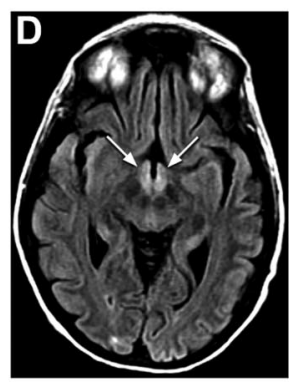

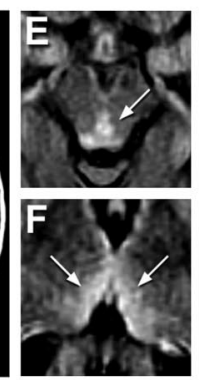

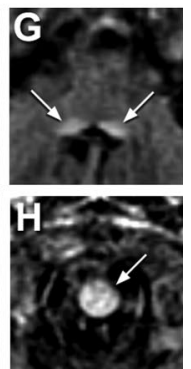

Figure. (A) Gadolinium-enhanced T1-weighted axial MRI shows symmetric enhancement of the mamillary bodies (paired arrowheads). (B) Enlarged axial view of the region of the hypothalamus showing mamillary body enhancement (paired arrowheads). (C) Enlarged coronal view of the mamillary body enhancement (paired arrowheads). (D) FLAIR hyperintensity of the hypothalamus is seen in an axial view (arrows). (E) FLAIR hyperintensity of the periaqueductal gray (arrows). (F) FLAIR hyperintensity of the dorsomedian thalamus (arrows). (G) FLAIR hyperintensity of the floor of the fourth ventricle (arrows). (H) FLAIR hyperintensity is seen throughout the low medulla (arrows).

\section{A clinical and radiographic variant of Wernicke-Korsakoff syndrome in a nonalcoholic patient}

A.C. Flint, MD, PhD; Y. Anziska, MD; M.E. Rausch, MD; T.J. Herzog, MD; and O. Williams, MD, MS, San Francisco, $C A$ (A.C.F.); New York, NY (Y.A., M.E.R., T.J.H., O.W.)

Wernicke-Korsakoff syndrome (WKS) is caused by thiamine deficiency and typically presents with encephalopathy, ataxia, and ophthalmoparesis.

A 57-year-old woman with no history of alcoholism developed abdominal distention over 4 months and an inability to eat. Abdominal/pelvic CT demonstrated a large midline mass. She

Disclosure: The authors report no conflicts of interest.

Address correspondence and reprint requests to Dr. Alexander C. Flint, University of California San Francisco, Department of Neurology, Neurovascular Service and Neurocritical Care, 505 Parnassus Avenue, Room M-830, San Francisco, CA 94143-0114; e-mail: alexander.flint@gmail.com underwent TAH/BSO with debulking of Stage IV metastatic endometrial adenocarcinoma. Nine days postoperatively she became lethargic and was disoriented and unable to register three objects. There was nystagmus in all directions but no ophthalmoparesis. Twelve hours later she had ophthalmoparesis not overcome by the oculocephalic maneuver. Symmetric limb ataxia and mild weakness progressed to dense quadriparesis.

Head CT showed no abnormalities. Brain MRI showed several characteristic findings of WKS (figure). The whole blood thiamine level was $1.0 \mu \mathrm{g} / \mathrm{dL}$ (normal 1.6 to $4.0 \mu \mathrm{g} / \mathrm{dL}$ ).

Following the initial examination, the patient was treated with IV thiamine. Four days later, she was alert and attentive, with normal extraocular movements, no nystagmus or ataxia, and normal strength. Unfortunately, she was left with a Korsakoff's amnestic syndrome.

This case was unusual in that there was dense quadriparesis ${ }^{1}$ with central and anterior medullary involvement. This nonalcoholic patient ${ }^{2}$ developed WKS from cancer-related malnutrition.

1. Kinoshita Y, Inoue Y, Tsuru E, Yasukouchi H, Yokota A. Unusual MR findings of Wernicke encephalopathy with cortical involvement. No To Shinkei 2001;53:65-68.

2. Ogershok PR, Rahman A, Nestor S, Brick J. Wernicke encephalopathy in nonalcoholic patients. Am J Med Sci 2002;323:107-111. 


\section{Neurology}

\section{A clinical and radiographic variant of Wernicke-Korsakoff syndrome in a nonalcoholic patient}

A. C. Flint, Y. Anziska, M. E. Rausch, et al.

Neurology 2006;67;2015

DOI 10.1212/01.wnl.0000232728.18186.23

\section{This information is current as of December 11, 2006}

\section{Updated Information \&} Services

Supplementary Material

References

Subspecialty Collections

Permissions \& Licensing

Reprints including high resolution figures, can be found at: http://n.neurology.org/content/67/11/2015.full

Supplementary material can be found at: http://n.neurology.org/content/suppl/2007/05/31/67.11.2015.DC1

This article cites 2 articles, 0 of which you can access for free at: http://n.neurology.org/content/67/11/2015.full\#ref-list-1

This article, along with others on similar topics, appears in the following collection(s):

All Neuro-ophthalmology

http://n.neurology.org/cgi/collection/all_neuroophthalmology

MRI

http://n.neurology.org/cgi/collection/mri

Nutritional

http://n.neurology.org/cgi/collection/nutritional

Ocular motility

http://n.neurology.org/cgi/collection/ocular_motility

Information about reproducing this article in parts (figures,tables) or in its entirety can be found online at:

http://www.neurology.org/about/about_the_journal\#permissions

Information about ordering reprints can be found online:

http://n.neurology.org/subscribers/advertise

Neurology ${ }^{\circledR}$ is the official journal of the American Academy of Neurology. Published continuously since 1951, it is now a weekly with 48 issues per year. Copyright . All rights reserved. Print ISSN: 0028-3878. Online ISSN: 1526-632X.

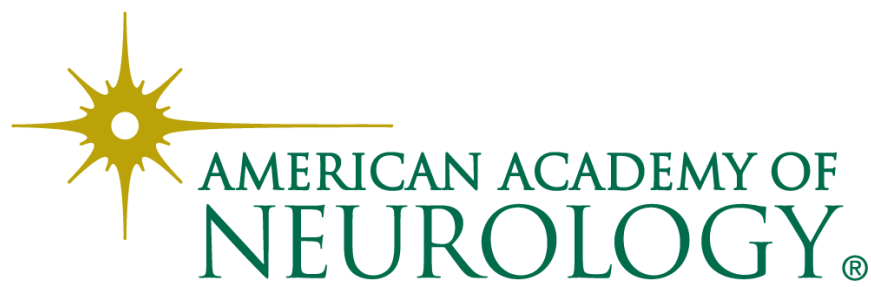

